\title{
Length- Weight Relationships and Condition Factors of Cynoglossus Cynoglossus and Caranx Hippos in Epe Lagoon, Nigeria
}

\author{
Josef Bamidele Bolarinwa
}

Department of Fisheries and Aquaculture Technology, Federal University of Technology, Akure, Ondo State,

Nigeria

\begin{abstract}
The length-weight relationships and condition factor ' $\mathrm{K}$ ' of 200 specimens of Cynoglossus cynoglossus and Caranx hippos of Epe lagoon conducted for 6 months (May-October,2015) showed that their growth patterns were described by the formula: $\log \mathrm{W}=-0.679+2.02 \log \mathrm{TL}$ and $\log \mathrm{W}=-2.49+3.467 \log \mathrm{TL}$ respectively. A high positive correlation coefficient ' $r$ ' of 0.97 exists between the length and weight of Cynoglossus cynoglosus that of Caranx hippos was 0.95 . The b value of 2.02 observed for C.cynoglossus showed its growth pattern was negatively allometric while that of Caranx hippos was positively allometric at 3.47 (T-test showed there was significant difference from 3.0 at $\mathrm{P}<0.05$ ). K factor of 0.48 was recorded for C.cynoglossus while that of Caranx hippos was 2.24.. The fact that $\mathrm{K}$ value of Caranx hippos was higher than that of Cynoglossus cynoglossus shows higher suitability of Epe lagoon for the former. There is therefore a need to conduct a more indepth research on the physiochemical parameters of the lagoon in view of the nearness to industrial areas of Epe and Ikorodu coupled with the highly anthropogenic activities around the lagoon. Future study on lengthweight relationships should span not less than 12 months to cover the two hydrological cycles.
\end{abstract}

Keywords: Allometry, condition factors, length-weight relationships,corellation

\section{INTRODUCTION}

Fish plays an important role in the development of a nation. Apart from being a cheap source of highly nutritive protein, it also contains other essential nutrients required by the body (Ayoade, 2011; Bolarinwa, 2013; Balogun, 2015). The fishery sector is a very important sector in the Nigeria agricultural development matrix. It provides employment for citizens in the coastal areas. In terms of Gross Domestic product (GDP), the fishery sector recorded the fastest growth rate when compared with other agricultural subsectors like forestry, livestock and has continued to grow in importance over the years particularly as a substitute to beef. Recent studies confirm the increasing shift from meat to fish consumption among households in Nigeria (Balogun, 2015). The fish fauna of the Nigerian fresh water systems has been a focus of research for quite sometimes (Idodo - Umeh, 1987). These studies concentrated more on the rivers, with less attention on the potentially productive brackish, natural lakes and coastal wet lands which are areas very susceptible to pollution and environmental degradation due to diverse anthropological activities capable of endangering some of these fishes.

The length-weight relationship is very important for proper exploitation and management of the population of fish species (Anene, 2005). Length and weight data are useful as standard result of fish sampling programs. These data are needed to estimate growth rates, length and age structures. (Bolarinwa, and Popoola, 2013). Other works on length-weight relationships of fish include (Kamaruddin et al., 2011; Kumolu-Johnson and Ndimele, 2010).

Condition factor $(\mathrm{k})$ compares the wellbeing of a fish and is based on the hypothesis that heavier fish of a given length are in better condition (Bagenal and Tesch, 1978). Condition factor has been used as an index of growth and feeding intensity (Solarin and Kusemiju, 2007). Condition factor decreases with increase in length and also influences the reproductive cycle in fish (Kumolu-Johnson, 2010). Condition factors of different species of cichlid fishes have been reported ( Arawomo, 1992; Yakub and Ansa, 2007). 
Josef Bamidele Bolarinwa "Length-Weight Relationships and Condition Factors of Cynoglossus Cynoglossus and Caranx Hippos in Epe Lagoon, Nigeria"

The objectives of the study are to evaluate the length and weight relationships and condition factors of Caranx hippos and Cynoglossus cynoglossus which are two dominant and highly demanded species in Epe lagoon. Caranx hippos otherwise called common jack, yellow cavalli. It is locally known as 'owere' among the Yorubas of Nigeria is characterized by its deep body, fins colouration and fins rays and lateral line scale counts. It is the largest fish in the genus with known length of $124 \mathrm{~cm}$ and weight $32 \mathrm{~kg}$. it is a common species found in large marine fishes classified within the jack family of Carangidae (Olaosebikan and Raji, 2011).

Cynoglossus cynoglossus (tongue sole) is locally known as 'abo' among the Yoruba-speaking tribe of Nigeria. It has dorsal soft rays number between 95 and 102 and the soft rays between 72 and 78, and is commonly found in brackish water muddy or sandy bottom off the coast where it feeds on benthic vertebrates. Other species include: Cynoglossus abbreviatus, Cynoglossus acaudatus, Cynoglossus arel, Cynoglossus attenuates, Cynoglossus billineatus, Cynoglossus browni, Cynoglossus dispar, Cynoglossus dibius, Cynoglossus gracilis (Adesulu and Syndenham, 2007).

\section{MATERIALS AND METHODS}

\section{Study Area}

The study area is Epe lagoon. Epe is under Epe local government with total population of 181,409 as at 2006 census and is one of the local government created by Federal Government of Nigeria in Lagos state. Epe lagoon lies between latitudes $03050^{\prime}-04010^{\prime} \mathrm{N}$ and longitudes $005030^{\prime}-005040^{\prime} \mathrm{E}$ is fed by River Oshun, it has a surface area of more than $243 \mathrm{~km}^{2}$ (about $225 \mathrm{~km} 2$ ) and a maximum depth of 6 $\mathrm{m}$ though a large area of the lagoon is relatively shallow with a minimum depth of $1 \mathrm{~m}$, and the vegetation surrounding the Lagoon is of the mangrove swampy type (Fafioye and Oluajo, 2005).

Epe lagoon is sandwiched between two other lagoons, the Lekki lagoon (freshwater) in the east and Lagos lagoon (brackish water) in the west. The lagoon opens into the Gulf of Guinea (the sea) via the Lagos Harbour.

The study area is predominantly by Yoruba indigenes and other tribes like the Eguns, Ilajes, Ijebus, Tivs and Ijaws forming the minority groups. The primary occupation in this locality is fishing. Artisanal fishers within the lagoon mainly exploit the fisheries using wooden/dug-out canoes ranging in size from $3 \mathrm{~m}$ to $8 \mathrm{~m}$ long. The canoes are either paddled or powered by small outboard engines, and manned by an average of two men. From these boats, the fishers operate their cast nets, hook and lines, gillnet, stow nets, traps, lift nets, long line, basket traps etc.

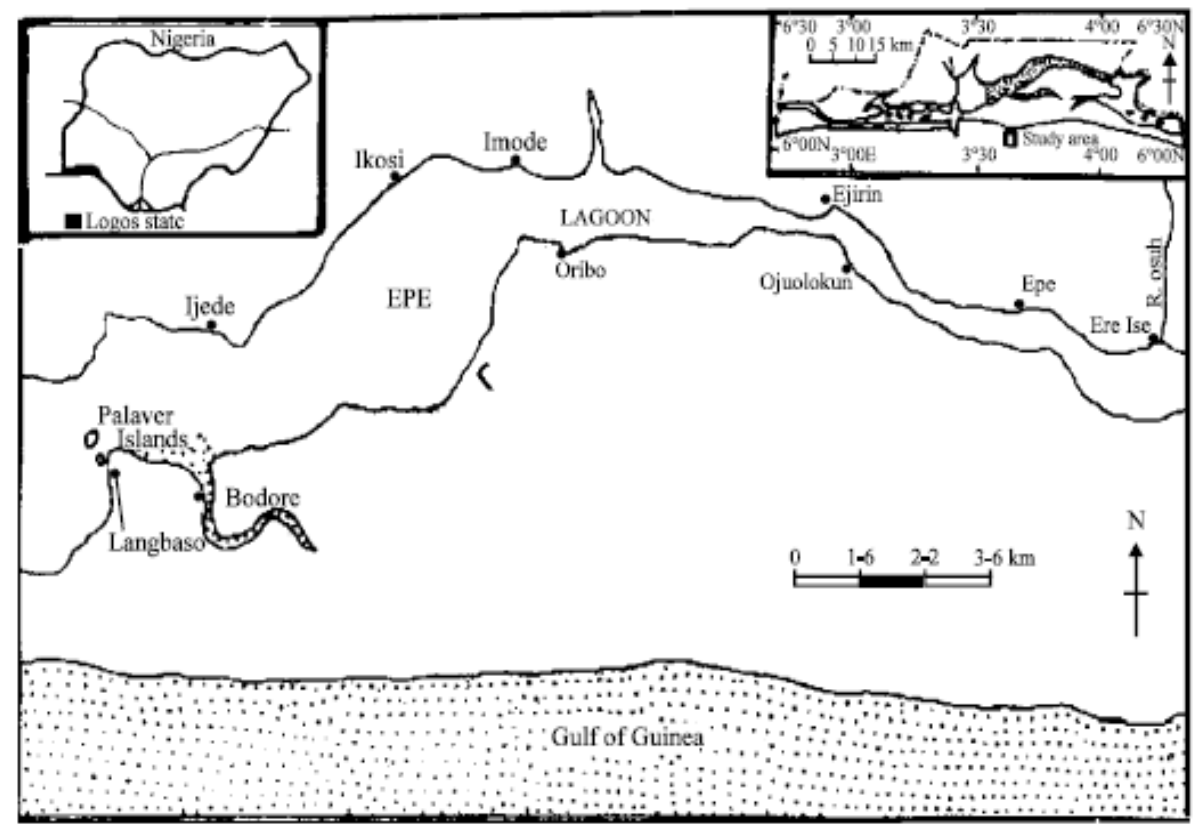

Fig1. Map Showing the Study Area

Length and weight relationship was achieved by getting the fishes available, a tape -rule and a sensitive weighing scale to measure the length and weight respectively. About 100 specimens of Cynoglossus cynoglossus and 100 of Caranx hippos were collected. Fish of different species was 
Josef Bamidele Bolarinwa "Length-Weight Relationships and Condition Factors of Cynoglossus Cynoglossus and Caranx Hippos in Epe Lagoon, Nigeria"

obtained from the catches of local fishermen at "Chief market" fish landing station located at Epe Lagoon. The fishes were identified using field guide to the commercial marine resource of Nigeria and fish base textbooks on taxonomy of fish species by Olaosebikan \& Raj i(1997) as well as Adesulu and Syndenham(2007). Measurement of the length and weight was determined with the aid of tape rule and weighing scale.

The Length - weight relationships (LWR) were estimated by using the equation:

$\mathrm{W}=\mathrm{a} \mathrm{L}{ }^{\mathrm{b}}$ where $\mathrm{W}=$ Weight $(\mathrm{g}), \mathrm{L}=$ total length $(\mathrm{cm}), \mathrm{a}=$ Constant and $\mathrm{b}=$ Growth exponent. The data on weight and total length were linearised by a logarithmic transformation to give: $\log \mathrm{W}=\mathrm{a}+$ $\mathrm{b} \log \mathrm{T} \mathrm{L}$. The values of the growth exponent $\mathrm{b}$ were used to calculate the condition factor, $\mathrm{K}=$ $100 \mathrm{~W} / \mathrm{L}^{\mathrm{b}}$ where $\mathrm{K}=$ Condition Factor, $\mathrm{W}=$ Total body weight $(\mathrm{g}), \mathrm{TL}=$ Total Length $(\mathrm{cm})$ and $\mathrm{b}=$ Growth exponent( the values of which determine the pattern of growth of the two fishes(Hart and Abowei, 2007: Solarin and Kusemiju, 2007).

\section{RESULTS AND DISCUSSION}

Change in $b$ values is subject to the shape and fatness of the species and it is also dependent on factors such as sex, spawning frequency, season, biogenic capacity of the environment (Olapade and Tarawallie, 2014). The length-weight relationship is very important for proper exploitation and management of the population of fish species (Anene, 2005, Fafioye and Oluajo, 2005).

The b value of 2.02 observed for Cynoglossus cynoglossus showed its growth pattern was negatively allometric while that of Caranx hippos was positively allometric at 3.47 (T-test showed there was significant difference from 3.0 at $\mathrm{P}<0.05$ ). Allometric growth patterns of both fishes show the dimensional growth rate of the two fishes are not the same. Most fishes exhibit such growth pattern. Bolarinwa(2015 ) observed negative allometric growth for the nine dominant fishes found in the coastal waters of Ondo State, Nigeria.These include Clarias gariepinus, Oreochromis niloticus, Coptodon zilli, Heterobranchus bidorsalis, Heterotis niloticus, Chrysichthys nigrodigitatus, Gymnarchus niloticus, Parachana africanna and Parachana obscura. Isometric growth pattern of fish is uncommon in nature (Olopade and Tarawallie, 2014, Bolarinwa, 2012, 2015).

Table1. Linearised Total Weight and Total Length of Cynoglossus cynoglossus and Caranx hippos in Epe lagoon

\begin{tabular}{|l|l|l|l|l|l|l|l|}
\hline $\mathrm{S} / \mathrm{N}$ & SPECIE & LOCAL NAME & $\mathrm{b}_{\mathrm{o}}$ & $\mathrm{B}_{1}$ & $\mathrm{Sig}$ & $\mathrm{R}^{2}$ & Fvalue \\
\hline 8 & Cynoglosus cynoglossus & Abo & -679 & 2.020 & 0.000 & .973 & 1234.247 \\
\hline 9 & Caranx hippos & Owere & -2499 & 3.467 & & .949 & 412.911 \\
\hline
\end{tabular}

Source: Field Study, 2015.

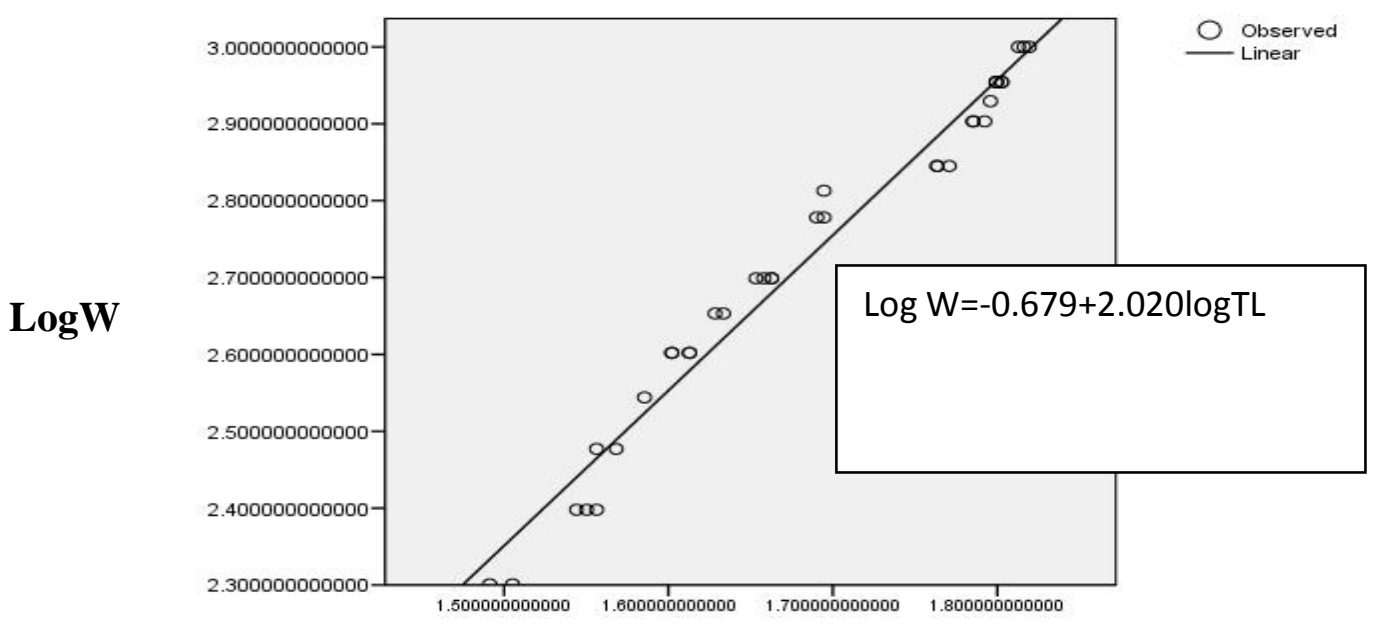

\section{$\log$ TL}

Figure2. Length-Weight Relationship of Cynoglosus cynoglossus in Epe lagoon. 
Josef Bamidele Bolarinwa "Length-Weight Relationships and Condition Factors of Cynoglossus Cynoglossus and Caranx Hippos in Epe Lagoon, Nigeria"

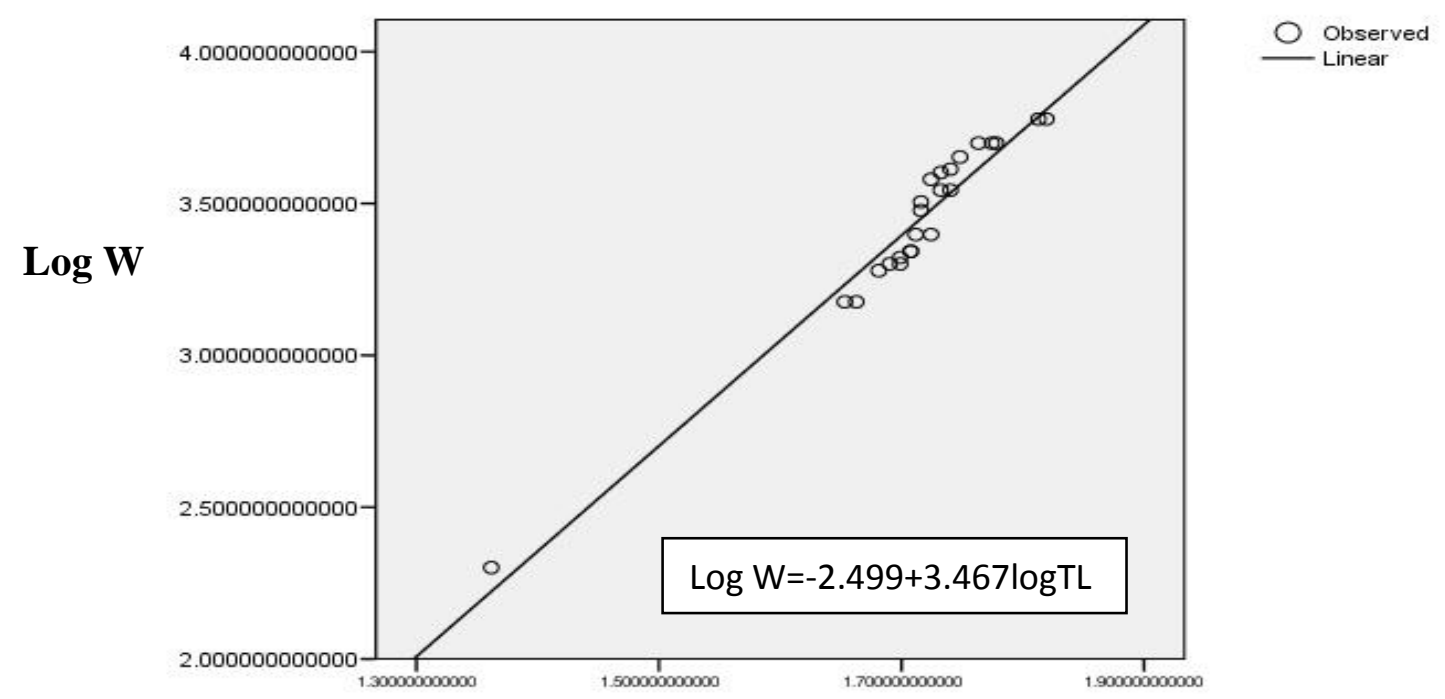

$\log$ TL

Figure3. Length-Weight Relationship of Caranx hippos in Epe lagoon.

\section{Condition Factors of Cynoglossus Cynoglossus and Caranx Hippos in Epe Lagoon}

The condition factor K of Cynoglossus cynoglossus was observed to be lower at 0.48 than that of Caranx hippos which was 2.24 in Epe lagoon showing the marine environment was more conducive for Caranx hippos than for Cynoglossus cynoglossus. According to Bolarinwa (2016), suitable condition factor for mature fishes in brackish water is 1 or greater than 1. Bagenal and Tesch (1978) recommended 2.9-4.8 as suitable condition factor for mature fresh water fish. However the estimated condition factor for C.cynoglossus being lower than 1 revealed the unconduciveness of Epe lagoon for $C$. cynoglossus. There would be need for more studies on condition factor of other fish species in Epe lagoon to be able to establish the conduciveness of Epe lagoon for fish survival.

\section{CONCLUSION AND RECOMMENDATIONS:}

The study revealed the growth patterns and condition factors of Cynoglossus cynoglossus and Caranx hippos found in Epe lagoon. The results reflect the level of wellbeing of these two highly consumed fishes by Nigerians especially inhabitants of Lagos State of Nigeria, a highly populated area with a lot of industries whose effluents if not well disposed could adversely affect aquatic life. Epe Lagoon is still more favourable to Caranx hippos than to Cynoglossus cynoglossus but there is a need for constant monitoring of the water physicochemical parameters to guarantee its suitability for fish growth and survival. There is therefore a need for more indepth studies on the pollution status of Epe lagoon.

\section{REFERENCES}

[1] Adesulu, E.A and Syndenham, D,H.J (2007). The Freshwater Fishes and Fisheries of Nigeria, Mac- Millan Nigeria Publishers Limited, Ibadan, Nigeria, pp 6-130.

[2] Anene, A., (2005). Condition factors of four cichlid species of a man-made lake in Imo state, Southeast, Nigeria. Turk. J. Fish. Aquat. Sci., 5: 43-47.

[3] Ayoade, A.A., (2011). Length- relationship weight and diet of African carp Labeo (Boulenger, 1910) in Asejire Lake Southwestern Nigeria. J. Fish. Aquat. Sci., 6: 472-478.

[4] Balogun, A.M(2015). The Fisheries subsector in a Declining Oil-based Economy; Paradigm shift for Economic Diversification and Employment Generation. Keynote address delivered at The $30^{\text {th }}$ annual conference of Fisheries Society of Nigeria, Asaba, Nigeria.pp1-28.

[5] Bolarinwa,J.B (2012). Growth pattern and condition factor of Elops lacerta in the Brackish water ponds of Buguma, River state, Nigeria, IRCAB. International Journal of Natural Sciences 2 (2): $34-45$. 
Josef Bamidele Bolarinwa "Length-Weight Relationships and Condition Factors of Cynoglossus Cynoglossus and Caranx Hippos in Epe Lagoon, Nigeria"

[6] Bolarinwa, J.B and Popoola,Q(2013). Length-weight relationship and condition factors of six economic fishes of Ibeshe water side, Lagos Lagoon, Nigeria. Proceedings of the international conference on Oceanography, Orlando-Florida, U.S.A, pp54-59.

[7] Bolarinwa, J.B(2015). Ichthyofauna resources of the coastal waters of Ondo State, Nigeria. Ph.D Thesis. Federal University of Technology, Akure, Nigeria.

[8] Bolarinwa,J.B(2016).Species composition and Diversity of the coastal waters of Ondo State, American Research Journal of Agriculture (ARJA) vol. 2016;1-7.ISSN2378-9018.

[9] Fafioye, O.O and Oluajo, O.A (2005). Length-weight relationship of five species in Epe lagoon, Nigeria, African Journal of Biotechnology 4(7):749-751

[10] Hart, A. I. and Abowei, J. F. N. (2007): A Study of the length-weight Relationship, condition factor and age of ten fish species from the lower Nun river. Niger Delta. Afr. J. Appl. Zool. Environ. Biol., 9: 13-19.

[11] Idodo-Umeh, G. (1978): Studies on the Fish Community of River Ase, Bendel State with special emphasis on the Food and Feeding Habit of Citharinidae, Bagridae, 45p

[12] Kamaruddin, I.S., Mustafa-Kamal, A.S, Christianus, A, Daud, S.K, Amin, SM.N and YuAbit, L (2011). Length-weight relationship and condition factor of three dominant species from the lake Tasik Kenyir, Terengganu, Malaysia. J. Fish. Aquatic Sci., 6: 852.

[13] Kumolu-Johnson,C.A and Ndimele, P.E(2010). Length-weight relationships and condition factors of Twenty-one fish species in Ologe lagoon, Lagos, Nigeria, Asian Journal of Agricultural Sciences, 2(4): 174-179.

[14] Olopade, J.O and Tarawallie, S (2014). The Length-weight Relationship, condition factor and Reproductive Biology of Pseudotolithus senegalensis (Valenciennes,1833) in Tombo Western Rural District of Sieraleone, African Journal of Food, Agriculture, Nutrition and Development,14(6): 2176-2188.

[15] Omitoyin, S.A and Fregene, B.T (2008). Sources and Impact of microcredit on the productivity of artisanal fisher folks in Lagos lagoon, Proceedings of Fisheries Society of Nigeria, pp103(edited by Araoye, P and Omoniyi, I.T). 